\title{
CEO-shareholder incentive alignment around SEOs
}

\author{
Yi Jiang $^{\mathrm{a}}$ and Yilei Zhang ${ }^{\mathrm{b}}$ \\ ${ }^{a}$ Mihaylo College of Business and Economics, Cal State University-Fullerton, Fullerton, CA, 92831 \\ (657) 278-4363 yjiang@fullerton.edu \\ ${ }^{\mathrm{b}}$ College of Business and Public Administration, University of North Dakota, Grand Forks, ND, 58202 \\ (701) 777-3407 yilei.zhang@und.nodak.edu
}

\begin{abstract}
We examine CEO wealth changes around seasoned equity offerings (SEOs). We find when market reacts negatively to SEO announcement leading to losses in CEO's existing firm-related wealth, the CEO gets additional compensation grants to offset the losses. Although this appears to be a rentseeking activity, we find that the additional grants are mainly in the form of stock options which would have no value if stock price failed to pick up in the future. In this sense, the additional grants align the interests between shareholders and managers. Consistent with this argument, we show that in the long run, high-grant SEO group outperforms low-grant SEO group by 0.60-0.77 percentage points on monthly return basis.
\end{abstract}

JEL classification: G32, J33

Keywords: executive compensation; incentive alignment; seasoned equity offering 


\section{Introduction}

Are managerial incentives aligned with those of shareholders in major corporate equity financing decisions? It has been well documented that shareholders suffer negative abnormal returns around seasoned equity offerings (SEOs thereafter) (Loughran and Ritter, 1995; Houston and Ryngaert, 1997; Jegadeesh, Weinstein and Welch, 1993) ${ }^{1}$. One interpretation is that SEOs are associated with empire building and/or overinvestment. Managers tend to be too optimistic, which then leads to a tendency to overinvest - suggesting SEOs destroy shareholder value (Heaton, 2002; Lee, 1997). On the other hand, SEOs may be in the interest of long-run shareholders if they are intended to dilute overvaluation (Baker and Wurgler, 2002; Shleifer and Vishny, 2003). Datta et al. (2005) find that market reacts more negatively to SEO announcement with high executive equity-based compensation. The result is interpreted as market perceives high manager-shareholder interest alignment as a clearer signal that the firm is issuing overvalued equity. Brzel and Webb (2006) support the same over-valuation story by documenting a negative relationship between the proportion of CEO equity-based compensation and shareholder wealth change after SEO announcement. The wealth effects on shareholders have been well documented, but what is less well understood is how CEOs, who presumably have a prominent role in the decision to undertake SEOs, fare.

This is an important line of inquiry. The price drop associated with an SEO would hurt CEOs with significant equity holdings. If CEOs did not get additional compensation they may avoid SEOs even if SEOs are in the long-run interest of shareholders. Alternatively, if SEO represents empire building, a drop in incentive compensation following SEOs may deviate CEO

\footnotetext{
1 Literature has documented on average -3\% SEO announcement abnormal return, followed by another -3\% SEO issue day abnormal return. Loughran and Ritter (1995) find SEO firms underperform size and industry matched non-issuance firms over the five years following SEOs.
} 
incentives from the optimal level, leading to mis-alignment of shareholder-manager incentives. To prevent the inferior outcomes, it is rational for the board to adjust the compensation policy to provide CEOs with ex ante and/or ex post sufficient incentives. By analyzing CEOs wealth effect around SEOs, our study provides empirical examination on how CEO wealth changes around SEOs.

To get at the issue of how CEO wealth changes around SEOs and how it is related to their incentive alignment, we decompose CEO wealth into three components that vary with the degree of CEO control. One component is relatively uncontrollable by the CEO. We call it price effect. That is, the change in stock price alters the value of CEO’s prior unadjusted holdings, measured by filtering out the new grant by the board and the portfolio adjustment by CEOs themselves. A second component, CEO's own portfolio adjustment, is at CEO's discretion. It measures the ability of the CEO to alter holdings in anticipation of the SEO (Huddart and Lang, 2003; Cline and $\mathrm{Fu}, 2010)^{2}$. The third component, board compensation grant, reflects board's compensation decisions. The board compensation grant consists of two parts: standard compensation grant which preserves the inflation-adjusted value of prior year's grant level; and incremental grant which represents abnormal grant CEO receives upon the change of board compensation policy following an event. We set about to investigate the importance of these components around SEOs, which tend to associate with negative abnormal stock returns.

Not surprisingly we find that on average CEO experiences losses from adverse stock price changes as evidenced by the negative price effect. However, we document that CEO wealth actually increases around SEOs, primarily because of their own portfolio adjustment and

\footnotetext{
${ }^{2}$ Using Thomason Financial Insider Filing Data, Cline and Fu (2010) document on average 1.76\% of a firm’s total market cap is sold and exercised in the months around the SEO.
} 
incremental board compensation grants. The latter is the main cause of CEO wealth increase. After controlling for CEO's own portfolio adjustment, an increase in compensation granted by the board is more than enough to offset the negative stock price effects which should have hurt mangers with significant equity holdings. Moreover we find that the incremental board compensation is far more pronounced in SEO firms than in matching non-issuance firms; in SEO event years than in non-event years of our SEO sample. Our sample of SEO firms is further grouped into positive and negative stock price effect firms. Despite the adverse stock price movement, adjustments from the board and CEO himself are more than enough to offset the negative side of the price impact, and contribute more significantly to CEO's total wealth of negative price effect firms than of positive price effect firms. These results seem to indicate a disconnect between CEO compensation and outside shareholder wealth.

However, the above evidence is static and only considers the short-run shareholder and CEO welfare. We next investigate the long-run incentive alignment of managers and shareholders. We find the majority of additional compensation grants are stock options. These options, granted at the money following SEOs, would be worthless if the stock price did not increase. In this sense the additional grants aligns the long-run interest of shareholders and managers. To test this effect, we investigate the moneyness effect of the options awarded after SEO announcement. We find that negative price effect group has higher option moneyness than the positive price effect group, defined as the ratio of stock price each year to the option strike price, over five years after SEOs. The "at-the-money" option grant setup leads to the gains to both shareholders and CEOs in the long-run. The results confirms the ex post incentive alignment. 
To measure the long-run performance of SEO firms, we adopt the calendar-time portfolio method and follow Fama-French (1993) and Carhart (1997) to control for market, size and value factors, and momentum factor. We compare the performance across positive/negative price effect and high/low SEO groups. Results show that for negative price effect group, low-grant SEO group significantly underperforms while high-grant SEO group performs as expected; and high-grant group outperforms the low-grant group by $0.60-0.77$ percentage points on monthly return basis, which is also statistically significant. In addition, the performance difference between high grant/positive price effect group and high grant/negative price effect group is not significant; while the performance of low grant/negative price group is significantly lower than low grant/positive price effect group. The results strongly support the incentive alignment argument, indicating incremental grants provide CEO incentives which benefit shareholders in the long run.

The paper makes several significant contributions. First, our study contributes to the literature that examines CEO incentives around corporate events. We explicitly calculate the contribution of each wealth component to CEO total wealth effect. We include market price effect, CEO's own portfolio adjustment, the dynamic moneyness of option grant as well as the change in board compensation policy.

Second, this paper improves our understanding of corporate financing decision and shareholder-management incentive alignment. We directly address CEO wealth effect around SEOs from the perspective of losses and gains of CEOs. More importantly, we investigate how CEO wealth effect is related to shareholder interest, both in the short-run and long-run.

Third, our study contributes to the literature of the optimality explanation of prevailing compensation policy. Acharya et al. (2000) rationalize option repricing, although option 
repricing has been generally criticized as a reflection of rent extraction. Rajan and Wulf (2006) argue that CEO perks are not purely managerial excess but can serve to enhance management productivity. Unlike previous studies that have focused on the negative side of CEO pay increase (Bliss and Rossen, 2001; Harford and Li, 2007), we propose an optimality explanation for the practice of increasing CEO pay around an SEO event. However, we acknowledge that we cannot completely exclude the rent extraction argument and we are not in a position to draw an explicit line between optimal adjustment and excessive pay. Further research should shed more light on this issue.

The remainder of the paper is organized as follows. We develop testable hypotheses in Section 2. Section 3 describes sample and data. Section 4 presents our empirical tests. Section 5 concludes.

\section{Hypotheses development}

We examine CEO's firm related wealth around the SEO event. There are three factors that affect CEO's wealth change: market price movement, board compensation policy change, and CEO's own portfolio adjustment. Specifically, stock price change leads to the change of the value of CEO's stock and option holdings. The new compensation grant by the board may increase CEO's wealth. CEO can adjust his/her portfolio by selling stocks and/or exercising options to reduce future wealth loss.

CEO's stock and option portfolio value change due to the stock price movement reflects the incentive alignment between shareholders and managers to a large extent. However, CEO and shareholders differ in two aspects. First, CEO holds an under-diversified portfolio with personal wealth closely tied to firm value. Second, CEO's incentive horizon is relatively myopic 
while reprehensive shareholders generally have a longer horizon. It has been well documented in the literature that SEO firms typically experience negative abnormal returns upon the announcement. One major argument is that firms tend to finance via equity when their stocks are over-valued. SEO announcement reveals the overvaluation information to the market, triggering negative price movement towards the true value. As a result, CEO suffers a short-run loss in his or her existing equity holdings, which may adversely alter CEO incentives ex ante to undertake SEOs even though SEOs may be in the long-run interest of shareholders. Alternatively, negative market reaction may indicate that SEOs are associated with empire building and/or overinvestment due to the agency problem or managerial overconfidence. If this is the case, the price drop after SEO would shrink CEO's firm-related wealth, further weakening the incentive alignment between shareholders and managers.

We do not try to differentiate the two arguments on SEO. Instead, we analyze whether board can take action to remedy the potential problems. The board can increase the compensation grant after the SEO — especially when the negative price effect is observed — to provide ex ante incentive for CEOs to undertake SEOs (in the over-valuation case) or to better align shareholder-manager interests ex post (in the empire building case). However, the mechanism to compensate CEOs following poor stock market performance insulates CEOs from negative results. This may create agency problem and promote CEOs to extract additional rent at shareholders' cost. To provide an empirical answer to these two arguments, we advance the following testable hypotheses:

H1. A mechanism exists to compensate CEOs' short-run loss after SEOs.

This can be tested cross-sectionally by comparing the compensation between SEO firms and non-issuance matching firms; and time-seriesly by comparing SEO firms' compensation in 
event years versus non-event years. If compensation policy indeed changes to offset CEOs' short-run loss, we would expect CEOs get more grants in SEO firms and in event years; and the more negative the price movement is, the more compensation will be granted.

The additional grants, however, may represent either incentive alignment or rent extraction. We argue that the agency problem of rent extraction can be mitigated if the board chooses to grant equity-based compensation especially options in lieu of cash, leading to the following hypotheses:

H2. The additional grants are predominately stock option grants

Equity-based compensation limits the rent-seeking capacity of CEOs. Particularly, the additional option grants would be worthless if the stock price does not increase above the exercise price in the future, no matter how many options granted. In this sense the additional option grants may align the long-run interests of managers and shareholders.

To evaluate the long-run performance, we propose that the incentive alignment would predict:

H3.1 The additional option grants are associated with higher long-run moneyness of options granted to CEOs after SEO.

The long-run moneyness measures how much in-the-money the new granted options will be in the long run. Higher long-run moneyness suggests that the additional option grants motivate CEOs to promote the stock price, hence also benefit shareholders in the long-run.

H3.2 The additional grants promote SEO firms’ long-run stock market performance

It has been documented in literature that SEO firms under-perform the market and peer firms over three or five years after issuance (Loughran and Ritter, 1995). If additional grants align incentives, we would expect SEO firms with higher grant have higher (or less negative) 
long-run stock market performance, and the effect is more pronounced in SEO firms with negative price movement around announcement.

\section{Data and descriptive statistics}

We use the Thomson Financial's SDC Global New Issues database to obtain our SEO sample. We adopt the following screening rules to construct our event samples: 1 . The stock return data, financial statement data, and executive compensation data are available from CRSP, COMPUSTAT, and ExecuComp. 2. To minimize the influence of outliers in the analysis, firms are excluded if they have a market value less than $\$ 10$ million. 3. Utility firms (SIC=4900-4999) and financial firms (SIC=6000-6999) are excluded since they operate in a regulated environment and their characteristics differ substantially from nonregulated firms. The exclusion of utilities also allows for comparisons with other studies. 4 . We require that there exists at least 1 year lag between subsequent equity issues. Each sample SEO firm is paired with a peer non-issuance firm that has the closest market value and the same two-digit SIC code.

The resulting SEO sample consists of 565 events on 395 firms over 1993 to 2005. Table 1 reports the distribution of SEOs sample as well as subsamples of positive price effect SEOs and negative price effect SEOs by year. It appears that the number of our SEO firms fluctuates over years, suggesting it is important to control for year effect in regression analysis.

[Insert Table 1 about here]

Table 2 presents summary statistics for SEO event years, non-event years, and size and industry matched non-issuance firms. All dollar values are in 2006 constant dollars. For each group, we report mean, median and standard deviation of main firm and issuance characteristics, 
as well as risk and return variables. We also test on the significance of difference in means and medians across groups.

\section{[Insert Table 2 about here]}

The time-series comparison (event vs. non-event years of SEO firms) shows that the SEO does generate some changes in firm characteristics. Firm size is larger in the non-event years, which may be due to the fact that we have more post-event observations than pre-event observations (63\% post-event versus 37\% pre-event). Consistent with the effect of equity financing, SEO years have higher market-to-book, slightly higher leverage, lower ROA and internal cash flow. In addition, acquisition is higher in the event years, consistent with the argument that firms use SEOs to finance acquisition. Though the pre-event annual stock return is higher for event years, there is a larger decline in event-year stock return. This is consistent with the over-valuation hypothesis on equity issuance. It argues that the issuance of overvalued stock triggers the market revaluation of the stock, leading to poor stock performance following SEOs. We also document significantly negative excess returns (three-day CAR) around SEO announcement, consistent with literature.

The differences between SEO firms (event years) and the size-and-industry matched nonissuance firms are in line with the financing needs, costs and benefits of financing and the effects of financing on firms. SEO firms are larger with higher growth rate and lower ROA. Those firms have greater financing needs in capital expenditure and acquisition expenditure. However they rely less on internally generated funds in that they maintain higher dividend payout ratio and lower internal cash flows. Consequently, SEO firms have higher market leverage. The much higher pre-event annual stock return for SEO firms suggests the issuance window timing and 
deteriorating post-issuance performance. SEO firms also have higher firm total risk after the event (we use the same event date and timeframe to calculate the matching firms' risk).

\section{CEO wealth effect}

To investigate how CEO’s firm-related wealth changes around SEO, we decompose CEO wealth into three major components: price effect, board compensation grant, and CEO’s own portfolio adjustment. Generally, the number of shares in CEO's current portfolio = the number of shares in previous year's portfolio + number of new grant - number of shares (options) sold (exercised) by CEO during the year. If there is no additional grant or CEO's portfolio adjustment, the previous holdings are open positions whose values are subject to the market price change. Therefore we define the first component as price effect. The price effect of stock holdings is measured as CEO's stock holdings before SEO times $\left(\mathrm{P}_{1}-\mathrm{P}_{0}\right)$, where $\mathrm{P}_{0}$ and $\mathrm{P}_{1}$ are the fiscal year-end market price before and after the event, respectively. The price effect of option holdings is evaluated separately for vested and unvested option holdings, calculated as the number of vested or unvested option holdings times $\left[\mathrm{C}\left(\mathrm{P}_{1}\right)-\mathrm{C}\left(\mathrm{P}_{0}\right)\right]$, where $\mathrm{C}\left(\mathrm{P}_{0}\right)$ and $\mathrm{C}\left(\mathrm{P}_{1}\right)$ are BlackScholes value of options before and after the SEO. Core and Guay's (2002) method is used to calculate the Black-Scholes value for vested and unvested options.

The second and third components represent board compensation policy and CEO's own portfolio adjustment, respectively. We further divide the board compensation grant into two parts. One represents the standard part which preserves the inflation-adjusted value of standard compensation grant, measured as the CPI-adjusted compensation grant before the SEO. We denote the second part as incremental grant, which is measured as any difference between the new grant and standard grant. Note incremental grant can be positive, negative or zero, which is 
determined by CEO's negotiation power and/or the board's opinion on the implications of the policy decision.

The change of stock market condition and board compensation policy could affect CEO's portfolio risk and return. CEO can adjust his portfolio holdings to achieve his own return and risk objectives. The adjustment includes stock sales and/or option exercises. Stock sale is the number of shares sold times (P1 - P0), where P0 and P1 are the fiscal year-end market price before and after the event, respectively. Option exercise is the number of options sold times [C(P1) - $\mathrm{C}(\mathrm{P} 0)]$, where $\mathrm{C}\left(\mathrm{P}_{0}\right)$ and $\mathrm{C}\left(\mathrm{P}_{1}\right)$ are Black-Scholes value of options before and after the SEO. We measure the adjustment over the fiscal year from before to after SEO.

\subsection{SEO-event sample versus non-event samples}

From the above analysis, two major sources of CEO wealth change can be identified: the unadjusted component (price effect and standard grant) and the adjusted component (incremental grant and CEO’s own portfolio adjustment). Table 3 reports the components value of the sample SEO firms in event and non-event years, as well as the matching non-issuance firms. This enables us to do both time series comparison (SEO firms in the event years versus non-even years) and cross-sectional comparison (SEO firms versus non-issuance matching firms) to reveal the characteristics of CEO wealth effect around SEO. Table 3, Panel A reports the absolute value of each component and Panel B reports the percentage contribution of each component to the total wealth effect.

\section{[Insert Table 3 about here]}

The price effect assumes no new grant or CEO’s own adjustment, thus evaluates the effect of price movement on CEO's prior (un-adjusted) portfolio holdings. The results show that 
CEOs experience negative price effect on average in the SEO event year, consistent with the negative stock returns following SEOs. In this sense CEOs share the same losses with shareholders from the market reaction. Though in the non-event years CEOs also report negative price effect on average, the magnitude is smaller than those of event years. Accordingly, the price effect accounts for a smaller proportion to the total wealth effect for event year SEO firms, 22.34\%/21.76\% (mean/median), compared with 39.65\%/38.58\% and 43.80\%/49.10\% for the two control groups.

Despite the massive wealth losses under the market force, CEOs of SEO firms get positive wealth gains through two channels: the compensation grant adjustment by the board and CEO’s own portfolio adjustment. The time-series comparison shows that though standard grant (which preserves the CPI-adjusted previous grant level) remains stable both in absolute value and proportional contribution, incremental grant especially option grant is larger and contributes more to CEO wealth in event years. The cross-sectional comparison shows that in the absolute value, SEO firm CEOs get larger grants (standard and incremental) than non-issuance firm CEOs. Interestingly, the standard grant as proportion of total wealth effect is the same in both groups, while the incremental grant contributes more to the total wealth effect in SEO firms, 27.67\%/18.19\% (mean/median), compared with 18.50\%/10.80\% in non-issuance matching firms. Despite the average negative post-issuance market reaction, event-year CEOs get larger incremental compensation, which may partially compensate for the negative price effect. Although this type of gain is not shared by common stockholders, it is not clear whether it represents a disconnect between CEO compensation and shareholder wealth. If additional compensation promotes CEO incentive to pursue long-run benefit of shareholders, it supports incentive alignment hypothesis. 
Another adjustment is conducted by CEOs themselves. The selling (exercising) of stocks and stock options may help CEOs reduce the open portfolio position subject to the influence of the price change. Moreover it directly adds dollar value to CEO wealth. The results show CEOs of SEO event-years adjust their portfolios more actively around the event, as compared with those of non-event years and matching non-issuance firms. The proportional contribution of CEO portfolio adjustment, though not significant, is larger in SEO firms (event years) (30.17\%/23.77\%) than in SEO firms (non-event years) $(17.43 \% / 2.60 \%)$ and non-issuance firms (16.70\%/1.40\%). The proportional contribution of option exercising is significantly larger in SEO firms (event years) (13.21\%/8.16\%) than in SEO firms (non-event years) $(-0.35 \% / 0 \%)$ and non-issuance firms $(1.00 \% / 0 \%)$. CEO exercising serves as another vehicle to offset the negative price effect. In the sense that CEOs perceive the market consequence of the SEOs, they are at a better position than shareholders to hedge their portfolio.

We next examine the marginal difference of each wealth component given the existence of other components and whether the above documented differences between SEO firms and control firms are driven by other firm specific factors. To address these considerations, we combine the SEO and control firm samples. We define a dummy variable Issuance which takes on the value 1 for SEO firms (event-years) and the value 0 for SEO firms (non-event-years) or non-issuance firms. We then fit a logistic regression model defined below to this dummy variable using the SEO (event years) plus SEO (non-event years) sample and the SEO (event years) plus non-issuance matching sample. Table 4 reports the results. Column (1) and (2) correspond to the time-series sample and column (3) and (4) correspond to the cross-sectional sample.

$$
\text { Issuance }=\alpha_{0}+\alpha_{1} \times(\text { Wealth Component })+\beta \times \text { Controls }+\tau_{\mathrm{t}}+\lambda_{\mathrm{i}}+\mathrm{e}_{\mathrm{it}}
$$


[Insert Table 4 about here]

We use different components of CEO wealth as the independent variables. One specification includes price effect, standard compensation grant, incremental grant and CEO's own portfolio adjustment. In another specification, price effect is further decomposed into stock price effect and option price effect; incremental compensation grant is decomposed into incremental cash compensation, incremental restricted stock grant and incremental stock option grant; and CEO’s own portfolio adjustment is decomposed into stock sale and option exercise. We control for firm size (proxied by the logarithm of total assets), growth (market-to-book), performance (ROA), and relative issuance size. $\tau_{t}$ and $\lambda_{i}$ represent year and industry effects, respectively.

The multivariate results are generally consistent with the univariate analysis. The price effect is significantly more negative in SEO firms' event years than in SEO firms' non-event years; and more negative but insignificant in SEO firms (event years) than in non-issuance firms. The incremental compensation grant is significantly higher in SEO firms (event years), which is largely driven by the higher incremental option grant. Note that the incremental cash compensation is actually lower in SEO firms (event years). This indicates the importance of option grant to CEO wealth. The coefficient on CEO portfolio adjustment is not significant. However, the option exercise is significantly larger in SEO event years. The above evidence on stock options suggests that options are more sensitive to price movement and are more subject to board and CEO adjustments.

\subsection{Negative price effect versus positive price effect firms}


Per our wealth decomposition, CEO wealth loss on SEO is summarized in the price effect. CEOs are compensated via two contemporaneous adjustments: the adjustment of board compensation grant (incremental grant) and the portfolio adjustment by CEOs themselves. In this section, we explore the relationship between the wealth losses and gains and how CEOs make use of the mechanisms around SEOs.

We group our SEO firms into two categories: SEOs with negative price effect and SEOs with positive price effect. ${ }^{3}$ We identify 358 negative price effect SEOs and 207 positive price effect SEOs. Table 5 reports the components of CEO wealth effect of the two groups separately and compare the differences between the groups.

\section{[Insert Table 5 about here]}

The difference of price effect is striking by grouping criterion. As expected, the incremental grant is much higher in the negative price effect SEOs, which is mainly driven by the incremental option grant. CEO portfolio adjustment is also significantly larger in the negative price effect SEOs. The results of percentage contribution show the same pattern: non-cash incremental grant and CEO portfolio adjustment contribute significantly more to wealth effect in the negative price effect SEO group.

In sum, the split sample analysis reveals a general balance that plays around SEOs. The more the losses CEOs experience, the more compensations will be triggered. We show some

\footnotetext{
${ }^{3}$ Note that it does not mean CEOs in the positive price effect SEOs experience no loss. The price effect is defined based on the absolute price change but not on abnormal stock returns. We find high correlation between the threeday CAR and price effect: in the positive price effect group, 38.65\% of firms (80 out of 207) report negative CAR; whereas in the negative price effect group, 63.69\% of firms (228 out of 358) report negative CAR. In the paper we define the price effect in the wealth decomposition as it is more informative on firm's compensation policy. The price effect is directly observable. Moreover, the option grant is generally not indexed so the compensation policy is more affected by the actual than the relative performance.
} 
channels exist to compensate CEO's loss around SEO, including additional option grant (dominant factor) and CEO’s own trading activities. Note additional option grant will end up with zero value if the stock price does not increase in the future. In this sense it is ex ante evidence supporting incentive alignment hypothesis.

\section{Long-run Option Moneyness}

The above analyses are basically one-period effects. However, the CEO wealth evolution is a dynamic process (Boschen and Smith (1995)). CEO’s wealth loss thus has an additional compensation mechanism from the dynamic perspective. The most prominent long-run effect comes from the fact that the stock market reaction to the SEO event changes the strike price of newly-granted options. The strike price, together with the post-issuance firm performance, determines the probability the options would be in-the-money and the extent of the "moneyness". We define "long-run moneyness" as the ratio of stock price at each year from -1 to year 5 to the strike price of option grant in year 0 , where 0 is the event year.

\section{[Insert Table 6 here]}

Table 6 Panel A presents the mean and median long-run moneyness of option grant for SEO firms and control firms. For both mean and median, the newly granted option in the SEO event-years is first out-of-the money and then moves in-the-money. The mean/median moneyness goes from $0.96 / 0.81$ and $0.91 / 0.72$ in the years $(-1,0)$ and $(0,1)$ to $1.18 / 0.99$ and $1.18 / 1.01$ in years $(0,4)$ and $(0,5)$. The evolution of moneyness in non-event years and nonissuance firms is much smoother, with the moneyness higher in early years while lower in later years. All in all, SEO firms (event years) tend to have a higher chance for options to end in-themoney in the long-run with a deeper moneyness. 
Panel B compares the pattern of long-run moneyness evolution between negative price effect SEOs and positive price effect SEO. For the first two years period, the newly-granted options in the negative price effect SEOs are deep out-of-the money and move in-the-money later on. For the positive price effect SEOs, the moneyness evolution is U-shaped. In the first two year periods, the newly-granted options have higher moneyness level than that in the negative price effect SEOs. The moneyness then decreases in the middle two year periods, with the level lower than that of the negative price effect SEOs (in those SEOs the level is increasing). In the last two years period, the moneyness level increases but is still lower than that of the negative price effect SEOs.

Table 6 Panel B also reports the evolution of option intrinsic value on subsamples of negative price effect SEOs and positive price effect SEOs. We calculate "option intrinsic value" as the option grant number in year 0 times the difference of stock price at each year from - 1 to year 5 and the strike price of option grant in year 0 , where 0 is the event year. ${ }^{4}$ Positive intrinsic value represents the payoffs CEOs can obtain if exercising the options granted in SEO year in subsequent years. We find that negative price effect group experience significantly higher option value increase. In sum, the "at-the-money" option grant set-up leads to the gains in long-run; and the long-run option moneyness and option value change results confirms ex post incentive alignment.

\section{Long-run SEO performance}

\footnotetext{
${ }^{4}$ Note option intrinsic value should be non-negative; that is, the per share intrinsic value $=\max (0, \mathrm{P}-\mathrm{X})$ where $\mathrm{P}$ is the prevailing market price and $\mathrm{X}$ is the strike price. However, we calculate the per share "intrinsic value" as $(\mathrm{P}-\mathrm{X})$ to reflect how deeply the option is under the water.
} 
The above evidence supports incentive alignment and optimal contracting argument. That is, compensation is a tool to incentivize CEOs to engage in SEOs that would benefit shareholders in the long-run. However, it does not completely eliminate the rent exploration hypothesis. To further tap this issue, we explore long-run performance of the event firms. Lyon, Barber and Tsai (1999) point out that calendar time portfolio method eliminates the problem of cross-sectional dependence in stock performance. To evaluate the long-run performance of SEO firms, we adopt four-factor model to examine the returns on calendar time portfolios. We form rolling portfolios of SEO firms by above/below median incremental grant and positive/negative price effect. Thus we have four portfolios: high grant / positive price effect, high grant / negative price effect, low grant / positive price effect, and low grant / negative price effect. We use both equal-weighted and value-weighted methods to construct the portfolios. For each calendar month, we calculate the return on the portfolios of firms that undertake SEOs within the last three years of the calendar month. We then regress the portfolio returns on Fama-French (1993) market, size and value factors, and Carhart (1997) momentum factor. Table 7 reports the results. The dependent variables are monthly portfolio returns in regressions (1) and (2) and the difference in returns between portfolios in regression (3). Panel A report results using total incremental grant as grouping criterion and Panel B report results using incremental option grant as criterion.

[Insert Table 7 about here]

To conserve space, we only report the regression intercept, or alpha, which represents abnormal gains or losses over the testing periods, after controlling for pricing factors. For positive price effect SEOs, alpha is not significantly different between high and low grant groups. For negative price effect SEOs, alpha for high grant SEOs is positive but not significant, indicating they perform as expected on average. However, alpha for low grant SEOs is 
significantly negative, indicating under-performance in the long run. The difference in alpha between high and low incremental grant groups shows high-grant SEO group outperforms lowgrant group by $0.60-0.77$ percentage points on monthly basis, which is statistically significant. In addition, the alpha difference between high grant/positive price effect group and high grant/negative price effect group is not significant; while the alpha of low grant/negative price group is significantly lower than low grant/positive price effect group. The results strongly support the incentive alignment argument, indicating incremental grants provide CEO incentives which benefit shareholders in the long run.

\section{Conclusion}

We provide an incentive alignment explanation for the increase in CEO compensation grant after SEOs, especially when the market reacts negatively to the SEO announcement. We argue that the board may find it rational to compensate CEOs after negative price reaction. If the negative price reaction is due to the revelation of over-valuation, then additional compensation motivates CEO ex ante to not forgo SEOs. Alternatively, if the negative price reaction reveals empire building and/or managerial overconfidence, the additional compensation grant help restore the incentive alignment ex post.

Our empirical results show that despite the negative price effect on SEO announcement, CEO's overall firm-related wealth does not decrease. We further show that controlling for CEO's own portfolio adjustment, additional compensation grant from the board is the major component that offsets the negative price effect on CEO wealth. The additional grant is predominately stock option grant. CEOs receive more option grants when the price effect is negative than when the price effect is positive. The additional option grants would be worthless if the stock price failed 
to increase in the future. In this sense the empirical findings are consistent with incentive alignment hypothesis, although they do not exclude possibility of a rent extraction explanation.

We further analyze whether the additional grants aligns the long-run interests of shareholders and managers. We investigate the moneyness effect of the options awarded after SEO announcement. We find that negative price effect group has higher moneyness, defined as the ratio of stock price each year to the option strike price, over five years after SEOs. In the long run, high-grant SEO group outperforms the low-grant SEO group by 0.60-0.77 percentage points on the monthly return basis. The results support the incentive alignment argument, indicating incremental grants provide CEO incentives which benefit shareholders in the long run. 


\section{References}

Aboody, D., Kasznik, R., 2000. CEO stock option awards and the timing of corporate voluntary disclosures. Journal of Accounting and Economics 29, 73-100.

Acharya, V., John, K., Sundaram, R., 2000, On the optimality of resetting executive stock options, Journal of Financial Economics 57, 65-101.

Baker, M., Wurgler. J., 2002. Market timing and capital structure. Journal of Finance 57, 1-32.

Bliss, R.T., Rosen, R.J., 2001. CEO compensation and bank mergers. Journal of Financial Economics 61, 107-138.

Boschen, J., Smith, K., 1995. You can pay me now and you can pay me later: the dynamic response of executive compensation to firm performance. Journal of Business 68, 577-608.

Brzel, J., Webb, E., 2006. CEO compensation and the seasoned equity offering decision. Managerial and Decision Economics 27, 363-378.

Carhart, M., 1997. On persistence of mutual fund performance. Journal of Finance 52, 57-2.

Cline, B., Fu, X., 2010. Executive stock option exercise and seasoned equity offerings. Financial Management 39, 1643-1670.

Coles, J., Daniel, N., Naveen, L., 2006. Executive compensation and managerial risk-taking. Journal of Financial Economics 79, 431-468.

Core, J., Guay, W., 1999. The use of equity grants to manage optimal equity incentive levels. Journal of Accounting and Economics 28, 151-184.

Core, J., Guay, W., 2002. Estimating the value of stock option portfolios and their sensitivities to price and volatility. Journal of Accounting Research 40, 613-630.

Datta S., Iskandar-Datta, M., Raman, K., 2005. Executive compensation structure and corporate equity financing decisions. Journal of Business 78, 1859-1890.

Datta S., Iskandar-Datta, M., Raman, K., 2005. Stock ownership and the maturity structure of corporate debt. Journal of Finance 60, 2333-2350.

Fama, E., French K., 1993, Common risk factors in the returns on stocks and bonds, Journal of Financial Economics 33, 3-56. 
Guay, W., 1999. The sensitivity of CEO wealth to equity risk: an analysis of the magnitude and determinants. Journal of Financial Economics 53, 43-71.

Harford, J., Li, K., 2007. Decoupling CEO wealth and firm performance: the case of acquiring CEOs. Journal of Finance 62, 917-949.

Heaton, J., 2002. Managerial optimism and corporate finance. Financial Management 31, 33-45.

Houston, J., Ryngaert, M., 1997. Equity issuance and adverse selection: a direct test using conditional stock offers. Journal of Finance 52, 197-219.

Huddart, S., Lang, M., 2003. Employee stock option exercises: an empirical analysis. Journal of Accounting and Economics 21, 5-43.

Jegadeesh, N., Weinstein, M., Welch, I., 1993. An empirical investigation of IPO return and subsequent equity offerings. Journal of Financial Economics 34, 153-175.

Lee, I., 1997. Do managers knowingly sell overvalued equity?. Journal of Finance 52, 1439-1466.

Lie, E., 2005. On the timing of CEO stock option awards. Management Science 51,802-812.

Loughran, T., Ritter, J., 1995. The new issues puzzle. Journal of Finance 50, 23-51.

Lyon, J., Barber, B., Tsai, C., 1999. "Improved methods for tests of long-run abnormal stock returns,” Journal of Finance 54, 165-201.

Rajan, R., Wulf, J., 2006. Are perks purely managerial excess?. Journal of Financial Economics 79, 1-33.

Shleifer, A., Vishny, R., 2003. Stock market driven acquisitions. Journal of Financial Economics 70, 295-311. 
Table 1. Sample distribution by year

The table presents the distribution of sample SEO firms by year. The full sample consists of 565 SEO events during 1993-2005, which is split into two subsamples of 358 negative price effect SEOs and 207 positive price effect SEOs.

\begin{tabular}{cccc}
\hline Year & Full sample & $\begin{array}{c}\text { Negative price } \\
\text { effect SEOs }\end{array}$ & $\begin{array}{c}\text { Positive price } \\
\text { effect SEOs }\end{array}$ \\
\hline 1993 & 56 & 33 & 23 \\
1994 & 56 & 39 & 17 \\
1995 & 35 & 18 & 17 \\
1996 & 42 & 25 & 17 \\
1997 & 39 & 23 & 16 \\
1998 & 38 & 31 & 7 \\
1999 & 38 & 30 & 8 \\
2000 & 43 & 35 & 8 \\
2001 & 24 & 20 & 4 \\
2002 & 46 & 41 & 5 \\
2003 & 49 & 11 & 38 \\
2004 & 55 & 24 & 31 \\
2005 & 44 & 28 & 16 \\
Total & 565 & 358 & 207 \\
\hline
\end{tabular}




\section{Table 2. Descriptive Statistics}

The table reports descriptive statistics for 565 SEO firms in events years, non-event years and a size-and-industry matched sample of non-issuance firms over 1993-2005. Total Assets is the book value of firms' total assets. Market-to-book = (market value of equity + book value of debt) $/$ book value of total assets. Market leverage $=$ book value of debt / (book value of debt + market value of equity). ROA is the return on assets. Capital Expenditure and Acquisition are the dollar value of capital expenditure and acquisition scaled by total assets. Internal free cash flow $=$ (operating income - interest - dividend - tax) $/$ Total assets. Dividend payout $=$ annual cash dividends $/$ the number of common shares outstanding. Issue size is the dollar value of the issuance. Issue size is the dollar value of the issuance. Relative issue size is the issuance value scaled by total assets. CAR is the three-day $(-1,0,1)$ market-adjusted CAR, where day 0 is the filing date. Pre-event stock return and Stock return are the annual percentage shareholder return before and in the event year. Pre-event total risk and Total risk are the standard deviation of 250-day returns before and after the event. Asterisks on means and medians in the SEO firms (non-event years) and non-issuance firms column indicate they are significantly different from the corresponding means and medians in the SEO firms (event years) column. The difference in means t-test assumes unequal variances across groups when a test of equal variances is rejected at the $10 \%$ level. The significance level of the difference in medians is based on a Wilcoxon sum-rank test. All dollar values are in 2006 constant dollars. A $* * *$, $* *$, * denote significance at the $1 \%, 5 \%$, and $10 \%$ levels, respectively.

\begin{tabular}{|c|c|c|c|c|c|c|c|c|c|}
\hline & \multicolumn{3}{|c|}{ SEO firms (Event years) } & \multicolumn{3}{|c|}{ SEO firms (Non-event years) } & \multicolumn{3}{|c|}{ Non-issuance Matching Firms } \\
\hline & Mean & Median & Std. Dev. & Mean & Median & Std. Dev. & Mean & Median & Std. Dev. \\
\hline \multicolumn{10}{|c|}{ A. Firm Characteristics } \\
\hline Total Assets (\$mil) & 4,848 & 1,774 & 6,570 & $6,627 * * *$ & $2,484 * * *$ & 8,4442 & $2,207 * * *$ & $1,345^{* * *}$ & 1,823 \\
\hline Market-to-book & 2.76 & 2.28 & 1.47 & $2.49 * * *$ & $2.11 * * *$ & 1.25 & $2.53 * *$ & $1.91 * * *$ & 1.65 \\
\hline Market leverage & 0.21 & 0.20 & 0.13 & $0.20 *$ & 0.18 & 0.12 & $0.12 * * *$ & $0.09 * * *$ & 0.11 \\
\hline ROA & 0.11 & 0.11 & 0.06 & $0.12 * * *$ & $0.12 * * *$ & 0.06 & $0.13 * *$ & $0.12 * * *$ & 0.08 \\
\hline Capital Expenditure & 0.05 & 0.04 & 0.05 & 0.05 & 0.04 & 0.04 & $0.05 *$ & 0.05 & 0.04 \\
\hline Acquisition & 0.03 & 0.00 & 0.04 & $0.02 * * *$ & $0.00 * *$ & 0.03 & $0.01 * * *$ & $0.00 * *$ & 0.02 \\
\hline Internal cash flow & 0.07 & 0.06 & 0.05 & $0.07 * *$ & $0.07 * * *$ & 0.05 & $0.08 * * *$ & $0.08 * *$ & 0.06 \\
\hline Dividend pay-out & 0.37 & 0.10 & 0.49 & 0.39 & $0.19 * *$ & 0.47 & $0.30 * *$ & 0.11 & 0.34 \\
\hline Issue size & 253.1 & 134.4 & 352.0 & & & & & & \\
\hline Relative issue size & 0.13 & 0.09 & 0.14 & & & & & & \\
\hline \multicolumn{10}{|l|}{ B. Return and risk } \\
\hline CAR & -1.18 & -1.15 & 4.36 & & & & & & \\
\hline Pre-event stock return & 34.37 & 26.89 & 40.68 & $14.78^{* * *}$ & $11.67 * * *$ & 31.79 & $18.53 * * *$ & $13.18^{* * *}$ & 34.74 \\
\hline Stock return & 14.17 & 10.45 & 35.18 & 15.59 & 12.63 & 32.25 & 11.57 & 7.55 & 34.51 \\
\hline Pre-event total risk & 15.71 & 15.22 & 3.39 & 15.51 & 15.00 & 3.39 & 15.20 & $14.50^{* *}$ & 4.20 \\
\hline Total risk & 16.02 & 15.81 & 3.44 & 15.76 & 15.31 & 3.52 & $14.90 * * *$ & $14.30 * * *$ & 3.60 \\
\hline
\end{tabular}




\section{Table 3. Wealth Decomposition}

The table reports the dollar value of wealth decomposition (\$thou) and percentage attribution (\%) for 565 SEO firms (event years) versus SEO firms (non-event years); and versus size-and-industry matched non-issuance firms over 1993-2005. The price effect of stock holdings is measured as CEO's stock holdings before SEO times (P1 - P0), where P0 and P1 are the fiscal year-end market price before and after the event, respectively. The price effect of option holdings is evaluated separately for vested and unvested option holdings, calculated as the number of vested or unvested option holdings times [C(P1) - C(P0)], where $\mathrm{C}\left(\mathrm{P}_{0}\right)$ and $\mathrm{C}\left(\mathrm{P}_{1}\right)$ are Black-Scholes value of options before and after the SEO. Board compensation grant is divided into two parts. The standard part preserves the inflation-adjusted value of standard compensation grant, measured as the CPI-adjusted compensation grant before the SEO. Incremental grant is measured as any difference between the new grant and prior year's grant. Incremental grant include incremental cash grant, restricted stock grant, and stock options grant. CEO's own portfolio adjustment includes stock sales and option exercises. Stock sale is the number of shares sold times (P1 - P0), where P0 and P1 are the fiscal yearend market price before and after the event, respectively. Option exercise is the number of options sold times $[\mathrm{C}(\mathrm{P} 1)-\mathrm{C}(\mathrm{P} 0)]$, where $\mathrm{C}\left(\mathrm{P}_{0}\right)$ and $\mathrm{C}\left(\mathrm{P}_{1}\right)$ are $\mathrm{Black}$ Scholes value of options before and after the SEO. Asterisks on means and medians in the SEO firms (non-event years) and matching firm column indicate they are significantly different from the corresponding means and medians in the SEO firms (event years) column. The difference in means t-test assumes unequal variances across groups when a test of equal variances is rejected at the $10 \%$ level. The significance level of the difference in medians is based on a Wilcoxon sum-rank test. All dollar values are in 2006 constant dollars. A ***/a, **/b, */c denote significance at the $1 \%, 5 \%$, and $10 \%$ level, respectively.

\begin{tabular}{|c|c|c|c|c|c|c|c|c|c|}
\hline & \multicolumn{3}{|c|}{ SEO firms (event years) } & \multicolumn{3}{|c|}{ SEO firms (non-event years) } & \multicolumn{3}{|c|}{ Non-issuance Matching Firms } \\
\hline & Mean & Median & Std. Dev. & Mean & Median & Std. Dev. & Mean & Median & Std. Dev \\
\hline \multicolumn{10}{|c|}{ A. Dollar value of wealth (\$thou) } \\
\hline Price effect & $-2,407$ & -767 & 14,295 & $-972 * *$ & $-231 *$ & 11,069 & $-1,207^{*}$ & $407^{*}$ & 8,710 \\
\hline From direct stocks & -866 & -96 & 5,446 & $-78 * * *$ & $0 * * *$ & 4,565 & -547 & 0 & 4,090 \\
\hline From stock option & $-1,363$ & -302 & 6,031 & -930 & -163 & 5,210 & $-771 * *$ & 65 & 3,789 \\
\hline Compensation grant & 5,535 & 3,744 & 4,675 & 5,487 & $3,554^{*}$ & 5,039 & $3,681 * * *$ & $2,644 * * *$ & 2,788 \\
\hline Standard grant & 2,366 & 1,734 & 1,719 & 2,472 & 1,768 & 1,878 & $1,639 * * *$ & $1,380^{* * *}$ & 940 \\
\hline Incremental grant & 2,923 & 1,583 & 3,353 & $2,607 * *$ & $1,129 * * *$ & 3,570 & $1,967 * * *$ & $960^{* * *}$ & 2,318 \\
\hline Cash & 119 & 80 & 594 & $176^{* *}$ & 89 & 653 & 124 & 69 & 373 \\
\hline Restricted stk & 148 & 0 & 391 & $108^{* *}$ & $0 *$ & 332 & $32 * * *$ & $0 *$ & 66 \\
\hline Stock options & 2,509 & 1,112 & 2,949 & $2,223^{* *}$ & $893 * * *$ & 3,035 & $1,466^{* * *}$ & $600 * * *$ & 1,962 \\
\hline CEO portfolio adj. & 1,439 & 164 & 5,168 & $800^{* * *}$ & $39 * * *$ & 5,019 & $862 * *$ & 44 & 3,296 \\
\hline Stock sale & 1,136 & 111 & 4,322 & $658^{* *}$ & $26 * * *$ & 4,223 & $652^{* *}$ & 43 & 2,641 \\
\hline Option exercise & 175 & 0 & 429 & $118^{* * *}$ & 0 & 330 & $63 * * *$ & 0 & 191 \\
\hline Total wealth effect & 4,955 & 3,426 & 15,818 & 5,541 & 2,452 & 14,950 & 3,840 & 2,869 & 10,885 \\
\hline \multicolumn{10}{|c|}{ B. Percentage to total wealth change (\%) } \\
\hline Price effect & 22.34 & 21.76 & 88.58 & 39.65 & 38.58 & 82.40 & $43.80 *$ & $49.10^{*}$ & 78.70 \\
\hline
\end{tabular}




\begin{tabular}{crrrllllll} 
From direct stocks & 9.85 & 8.10 & 41.78 & 21.06 & 9.73 & 39.41 & $25.60^{* *}$ & $10.60^{* *}$ & 40.50 \\
From stock option & 14.95 & 15.65 & 52.99 & $20.22^{* *}$ & 12.78 & 48.75 & 23.00 & 17.50 & 45.00 \\
Compensation grant & 42.50 & 31.00 & 62.49 & $40.42^{* * *}$ & $38.90^{* * *}$ & 65.10 & 38.00 & 28.70 & 60.90 \\
Standard grant & 14.77 & 10.19 & 42.10 & 19.94 & 12.69 & 40.38 & 20.50 & 10.60 \\
Incremental grant & 27.67 & 18.19 & 33.21 & $20.31^{* * *}$ & $14.99 * * *$ & 33.63 & $18.50^{* * *}$ & $10.80^{* * *}$ & 30.10 \\
$\quad$ Cash & 2.18 & 0.86 & 8.73 & $3.21^{* *}$ & 1.05 & 10.46 & 2.20 & 0.60 & 8.40 \\
Restricted stk & 7.49 & 0.00 & 3.40 & $1.02^{*}$ & 0.00 & 3.68 & 0.70 & 0.00 & 1.30 \\
Stock options & 19.56 & 14.19 & 25.12 & $16.82^{* * *}$ & $9.03^{* * *}$ & 27.03 & 11.20 & 0.00 & 22.80 \\
CEO portfolio adj. & 30.17 & 23.77 & 46.33 & 17.43 & $2.26^{*}$ & 45.30 & 16.70 & 1.40 & 41.40 \\
Stock sale & 18.91 & 13.37 & 40.85 & 17.34 & 2.67 & 40.43 & 15.20 & 2.70 & 37.10 \\
Option exercise & 13.21 & 8.16 & 4.53 & $-0.35^{*}$ & 0.00 & 2.72 & $1.00^{* * *}$ & $0.00^{* * *}$ & 2.60 \\
\hline
\end{tabular}


Table 4. Wealth Decomposition: Multivariate Analysis

The dependent variable $=1$ for SEO firms (event years) and 0 otherwise. In columns (1) and (2), the sample is SEO firms in event and non-event years. In columns (3) and (4), the sample includes SEO firms (event years) and matching non-issuance firms. Wealth component variables are defined in Table 3. Firm characteristic variables are defined as in Table 2. Z-statistics are reported in parentheses below the parameter estimates. ${ }^{* *}, * *$, and $*$ indicate significance at the $1 \%, 5 \%$, and $10 \%$ level, respectively.

\begin{tabular}{|c|c|c|c|c|}
\hline \multirow{2}{*}{ Independent variables } & \multicolumn{4}{|c|}{ Dependent variable: equity issuance } \\
\hline & (1) & (2) & (3) & (4) \\
\hline Price effect & $\begin{array}{c}-0.011 \\
(-2.14)^{* *}\end{array}$ & & $\begin{array}{c}-0.008 \\
(-1.20)\end{array}$ & \\
\hline From direct stocks & & $\begin{array}{l}-0.036 \\
(-2.67)^{* * *}\end{array}$ & & $\begin{array}{c}-0.017 \\
(-0.78)\end{array}$ \\
\hline From stock options & & $\begin{array}{c}0.014 \\
(1.00)\end{array}$ & & $\begin{array}{c}0.022 \\
(0.97)\end{array}$ \\
\hline Standard compensation grant & $\begin{array}{c}0.064 \\
(2.01)^{* *}\end{array}$ & $\begin{array}{c}0.043 \\
(1.32)\end{array}$ & $\begin{array}{l}0.425 \\
(5.81)^{* * *}\end{array}$ & $\begin{array}{l}0.366 \\
(4.72)^{* * *}\end{array}$ \\
\hline Incremental compensation grant & $\begin{array}{l}0.054 \\
(3.93)^{* * *}\end{array}$ & & $\begin{array}{l}0.105 \\
(3.47)^{* * *}\end{array}$ & \\
\hline Cash compensation & & $\begin{array}{c}-0.160 \\
(-2.18)^{* *}\end{array}$ & & $\begin{array}{l}-0.231 \\
(-1.32)\end{array}$ \\
\hline Restricted stock grant & & $\begin{array}{c}0.430 \\
(3.11)^{* * *}\end{array}$ & & $\begin{array}{c}1.663 \\
(4.39)^{* * *}\end{array}$ \\
\hline Stock option grant & & $\begin{array}{l}0.067 \\
(3.93)^{* * *}\end{array}$ & & $\begin{array}{l}0.179 \\
(4.86)^{* * *}\end{array}$ \\
\hline CEO portfolio adjustment & $\begin{array}{c}0.015 \\
(1.63)\end{array}$ & & $\begin{array}{l}-0.013 \\
(-0.68)\end{array}$ & \\
\hline Stock sale & & $\begin{array}{c}0.014 \\
(1.29)\end{array}$ & & $\begin{array}{c}-0.023 \\
(-0.97)\end{array}$ \\
\hline Option exercise & & $\begin{array}{c}0.288 \\
(1.71)^{*}\end{array}$ & & $\begin{array}{l}1.039 \\
(3.45)^{* * *}\end{array}$ \\
\hline $\log \mathrm{TA}$ & $\begin{array}{l}-0.433 \\
(-8.22)^{* * *}\end{array}$ & $\begin{array}{l}-0.429 \\
(-8.10)^{* * *}\end{array}$ & $\begin{array}{l}0.280 \\
(3.44)^{* * *}\end{array}$ & $\begin{array}{l}0.284 \\
(3.35)^{* * *}\end{array}$ \\
\hline Market-to-book & $\begin{array}{l}0.198 \\
(4.93)^{* * *}\end{array}$ & $\begin{array}{c}0.186 \\
(4.25)^{* * *}\end{array}$ & $\begin{array}{l}0.316 \\
(5.60)^{* * *}\end{array}$ & $\begin{array}{c}0.279 \\
(4.78)^{* * *}\end{array}$ \\
\hline Market leverage & $\begin{array}{l}-0.233 \\
(0.28)\end{array}$ & $\begin{array}{c}-0.205 \\
(-0.25)\end{array}$ & $\begin{array}{c}7.439 \\
(10.46)^{* * *}\end{array}$ & $\begin{array}{c}7.775 \\
(10.43)^{* * *}\end{array}$ \\
\hline ROA & $\begin{array}{c}-5.428 \\
(-6.10)^{* * *}\end{array}$ & $\begin{array}{l}-5.494 \\
(-6.17)^{* * *}\end{array}$ & $\begin{array}{l}-4.333 \\
(-3.16)^{* * *}\end{array}$ & $\begin{array}{l}-3.991 \\
(-2.82)^{* * *}\end{array}$ \\
\hline Observations & 5,086 & 5,086 & 1,129 & 1,129 \\
\hline Pseudo $\mathrm{R}^{2}$ & 0.05 & 0.06 & 0.23 & 0.35 \\
\hline
\end{tabular}


Table 5. Wealth decomposition on negative price effect SEOs vs. positive price effect SEOs

The table reports the wealth change decomposition on subsamples of negative price effect SEOs and positive price effect SEOs. Wealth component variables are defined in Table 3. Asterisks on means and medians in the positive price effect SEO column indicate they are significantly different from the corresponding means and medians in the negative price effect column. The difference in means t-test assumes unequal variances across groups when a test of equal variances is rejected at the $10 \%$ level. The significance level of the difference in medians is based on a Wilcoxon sum-rank test. All dollar values are in 2006 constant dollars. A $* * * / a, * * / b, /^{\mathrm{c}}$ denote significance at the $1 \%, 5 \%$, and $10 \%$ levels, respectively.

\begin{tabular}{|c|c|c|c|c|c|c|}
\hline & \multicolumn{3}{|c|}{ Negative price effect SEOs $(\mathrm{N}=358)$} & \multicolumn{3}{|c|}{ Positive price effect SEOs $(\mathrm{N}=207)$} \\
\hline & Mean & Median & Std.Dev. & Mean & Median & Std.Dev. \\
\hline \multicolumn{7}{|c|}{ A. Dollar value of wealth (\$thou) } \\
\hline Price effect & $-8,440$ & $-4,439$ & 13,692 & $8,026 * * *$ & $4,645^{* * *}$ & 7,869 \\
\hline From direct stocks & $-3,046$ & $-1,426$ & 5,302 & $2,906 * * *$ & $1,304^{* * *}$ & 3,150 \\
\hline From stock option & $-3,843$ & $-1,804$ & 5,987 & $2,926 * * *$ & $1,911 * * *$ & 2,881 \\
\hline Compensation grant & 6,097 & 3,904 & 5,226 & $4,563 * * *$ & 3,518 & 3,317 \\
\hline Standard grant & 2,510 & 1,762 & 1,827 & $2,118^{* * *}$ & $1,645^{*}$ & 1,486 \\
\hline Incremental grant & 3,259 & 1,638 & 3,741 & $2,344 * * *$ & 1,549 & 2,447 \\
\hline Cash & 50 & 31 & 613 & $237^{* * *}$ & $65^{* * *}$ & 540 \\
\hline Restricted stock & 113 & 0 & 362 & $208^{* * *}$ & $0 * * *$ & 431 \\
\hline Stock options & 3,033 & 1,346 & 3,336 & $1,604 * * *$ & $989 * * *$ & 1,796 \\
\hline CEO portfolio adj. & 2,206 & 269 & 5,625 & $112^{* * *}$ & $26^{* * *}$ & 3,936 \\
\hline Stock sale & 1,562 & 144 & 4,676 & $400^{* * *}$ & $63^{*}$ & 3,519 \\
\hline Option exercise & 291 & 0 & 477 & $-24 * * *$ & $0 * * *$ & 215 \\
\hline Total wealth effect & 981 & 350 & 16,406 & $11,827 * * *$ & $8,439 * * *$ & 11,988 \\
\hline \multicolumn{7}{|c|}{ B. Percentage to total wealth change (\%) } \\
\hline Price effect & 38.99 & 35.17 & 104.36 & 48.12 & 44.67 & 50.55 \\
\hline From direct stocks & 18.67 & 3.73 & 46.80 & 21.90 & $10.41^{* * *}$ & 31.24 \\
\hline From stock option & 24.02 & 4.75 & 62.49 & 26.55 & $21.76^{* * *}$ & 30.27 \\
\hline Compensation grant & 27.62 & 12.52 & 73.32 & $40.94 * * *$ & $38.58 * * *$ & 35.54 \\
\hline Standard grant & 18.27 & 1.71 & 49.39 & 22.35 & $16.86^{* * *}$ & 24.78 \\
\hline Incremental grant & 7.36 & 0.02 & 37.27 & $19.12^{* * *}$ & $17.61^{* * *}$ & 22.91 \\
\hline Cash & 1.82 & 0.50 & 9.36 & 2.81 & $1.59 *$ & 7.49 \\
\hline Restricted stock & 0.42 & 0.00 & 3.21 & $1.32^{* * *}$ & $0.00^{* * *}$ & 3.66 \\
\hline Stock options & 9.79 & 0.00 & 28.76 & $14.61^{* *}$ & $10.75^{* * *}$ & 16.70 \\
\hline CEO portfolio adj. & 26.77 & 7.25 & 50.67 & $8.76^{* * *}$ & $3.10^{* * *}$ & 34.92 \\
\hline Stock sale & 24.35 & 5.53 & 44.72 & $9.50 * * *$ & $2.41^{* *}$ & 31.02 \\
\hline Option exercise & 0.55 & 0.00 & 4.49 & $-0.92 * * *$ & $0.00^{* * *}$ & 3.50 \\
\hline
\end{tabular}


Table 6. Long-run Option Moneyness

Panel A reports the long-run option moneyness for 565 SEO firms (event years) versus SEO firms (non-event years); and versus size-and-industry matched nonissuance firms over 1993-2005. Panel B reports the long-run option moneyness \& option intrinsic value on subsamples of negative price effect SEOs and positive price effect SEOs. We define "long-run moneyness" as the ratio of stock price at each year from -1 to year 5 to the strike price of option grant in year 0 , where 0 is the event year. We define "option intrinsic value" as the difference of stock price at each year from -1 to year 5 and the strike price of year 0 , multiplied by the number of option grants at year $0 . \mathrm{A}$ a/b/c on means and medians in the SEO firms (non-event years) and non-issuance matching firms column indicate they are significantly different from the corresponding means and medians in the SEO firms (event years) column at the $1 \%, 5 \%$, and $10 \%$ levels, respectively. A $\mathrm{a} / \mathrm{b} / \mathrm{c}$ on means and medians in the positive price effect SEO column indicate they are significantly different from the corresponding means and medians in the negative price effect column at the $1 \%, 5 \%$, and $10 \%$ levels, respectively.

Panel A. SEO firms (event years) versus SEO firms (non-event years) and Non-issuance firms

\begin{tabular}{|c|c|c|c|c|c|c|c|c|c|c|c|c|c|c|c|c|c|c|}
\hline \multirow[t]{2}{*}{ LR moneyness } & \multicolumn{6}{|c|}{ SEO firms (event years) } & \multicolumn{6}{|c|}{ SEO firms (non-event years) } & \multicolumn{6}{|c|}{ Non-issuance Matching Firms } \\
\hline & $(-1,0)$ & $(0,1)$ & $(0,2)$ & $(0,3)$ & $(0,4)$ & $(0,5)$ & $(-1,0)$ & $(0,1)$ & $(0,2)$ & $(0,3)$ & $(0,4)$ & $(0,5)$ & $(-1,0)$ & $(0,1)$ & $(0,2)$ & $(0,3)$ & $(0,4)$ & $(0,5)$ \\
\hline Mean & 0.96 & 0.91 & 0.98 & 1.03 & 1.18 & 1.18 & 0.97 & $1.01^{\mathrm{b}}$ & 1.04 & 0.97 & $1.05^{\mathrm{b}}$ & $1.05^{\mathrm{b}}$ & 0.96 & 0.87 & 0.97 & 0.96 & 1.06 & 1.06 \\
\hline Median & 0.81 & 0.72 & 0.82 & 0.86 & 0.99 & 1.01 & $0.89^{\mathrm{a}}$ & $0.89^{\mathrm{a}}$ & $0.89^{c}$ & $0.80^{\mathrm{b}}$ & $0.82^{\mathrm{a}}$ & $0.82^{\mathrm{a}}$ & $0.91^{\mathrm{a}}$ & $0.80^{\mathrm{b}}$ & $0.79^{\mathrm{b}}$ & 0.87 & 0.96 & 0.87 \\
\hline
\end{tabular}

Panel B. Negative price effect SEOs vs. positive price effect SEO

\begin{tabular}{|c|c|c|c|c|c|c|c|c|c|c|c|c|}
\hline LR moneyness & \multicolumn{6}{|c|}{ Negative price effect SEOs $(\mathrm{N}=358)$} & \multicolumn{6}{|c|}{ Positive price effect SEOs $(\mathrm{N}=207)$} \\
\hline \multirow{3}{*}{$\begin{array}{l}\text { Mean } \\
\text { Median }\end{array}$} & $(-1,0)$ & $(0,1)$ & $(0,2)$ & $(0,3)$ & $(0,4)$ & $(0,5)$ & $(-1,0)$ & $(0,1)$ & $(0,2)$ & $(0,3)$ & $(0,4)$ & $(0,5)$ \\
\hline & 0.85 & 0.72 & 1.19 & 1.15 & 1.29 & 1.23 & $1.04^{\mathrm{a}}$ & $1.05^{\mathrm{a}}$ & $0.83^{\mathrm{a}}$ & $0.94^{\mathrm{b}}$ & $1.09^{c}$ & 1.15 \\
\hline & 0.77 & 0.64 & 1.05 & 0.94 & 1.04 & 1.06 & $0.86^{\mathrm{a}}$ & $0.76^{\mathrm{a}}$ & $0.73^{\mathrm{a}}$ & $0.77^{\mathrm{a}}$ & $0.92^{\mathrm{b}}$ & $0.92^{\mathrm{C}}$ \\
\hline Option value & \multicolumn{6}{|c|}{ Negative price effect SEOs $(\mathrm{N}=358)$} & \multicolumn{6}{|c|}{ Positive price effect SEOs $(\mathrm{N}=207)$} \\
\hline \multirow{3}{*}{$\begin{array}{l}\text { Mean } \\
\text { Median }\end{array}$} & $(-1,0)$ & $(0,1)$ & $(0,2)$ & $(0,3)$ & $(0,4)$ & $(0,5)$ & $(-1,0)$ & $(0,1)$ & $(0,2)$ & $(0,3)$ & $(0,4)$ & $(0,5)$ \\
\hline & -454.95 & -849.24 & 576.27 & 454.95 & 879.57 & 697.59 & $64.16^{\mathrm{c}}$ & $80.20^{\mathrm{a}}$ & $-272.68^{\mathrm{a}}$ & $-96.24^{b}$ & $144.36^{\mathrm{c}}$ & $240.62^{c}$ \\
\hline & -309.58 & -484.56 & 67.30 & -80.76 & 53.84 & 80.76 & $-138.46^{\mathrm{b}}$ & $-237.36^{a}$ & $-267.03^{\mathrm{a}}$ & $-227.47^{\mathrm{a}}$ & $-79.12^{b}$ & $-77.52^{\mathrm{b}}$ \\
\hline
\end{tabular}


Table 7: Monthly alpha gains using Fama-French three-factor model

The table presents alphas (intercepts) of SEO firms based on high/low increment grant and positive/negative price effect. High (Low) Grant refers to the above (below) median incremental grant in Panel A. High (Low) Option Grant refers to the above (below) median incremental option grant in Panel B. We form rolling portfolios of SEOs by above/below median incremental grant and positive/negative price effect. For each calendar month, we calculate return on a portfolio of firms that undertake SEOs within the last three years of the calendar month. The dependent variables are the monthly portfolio returns in regressions (1) and (2) and difference in returns between groups in regression (3). The independent variables are price factors: market excess return, return of small minus big stocks, return of high minus low book-to-market stocks, and return of high return portfolios minus low return portfolios. The coefficients on the independent variables are not reported to conserve space. Each regression uses 192 monthly observations. T-statistics are reported in parentheses. A *, ** and *** denote significance level at the $10 \%, 5 \%$ and $1 \%$ levels.

Panel A: High Incremental Grant vs. Low incremental Grant

\begin{tabular}{|c|c|c|c|c|c|c|}
\hline & \multicolumn{3}{|c|}{ Equally-weighted alphas } & \multicolumn{3}{|c|}{ Value-weighted alphas } \\
\hline & (1) High Grant & 2) Low Grant & (3) Difference & (1) High Grant & (2) Low Grant & (3) Difference \\
\hline \multicolumn{7}{|c|}{ (1) Positive price effect SEOs: } \\
\hline & $\begin{array}{c}0.46 \\
(1.76)^{*}\end{array}$ & $\begin{array}{l}0.60 \\
(2.03)^{* *}\end{array}$ & $\begin{array}{c}-0.14 \\
(-0.46)\end{array}$ & $\begin{array}{c}0.40 \\
(1.35)\end{array}$ & $\begin{array}{l}0.58 \\
(1.77)^{*}\end{array}$ & $\begin{array}{c}-0.18 \\
(-0.48)\end{array}$ \\
\hline \multicolumn{7}{|c|}{ (2) Negative price effect SEOs: } \\
\hline & $\begin{array}{c}0.22 \\
(1.02)\end{array}$ & $\begin{array}{l}-0.44 \\
(-1.98)^{* *}\end{array}$ & $\begin{array}{c}0.66 \\
(2.33)^{* * *}\end{array}$ & $\begin{array}{c}0.11 \\
(0.46)\end{array}$ & $\begin{array}{l}-0.63 \\
(-2.14)^{* *}\end{array}$ & $\begin{array}{l}0.74 \\
(1.99)^{* *}\end{array}$ \\
\hline \multicolumn{7}{|l|}{ (3) Difference: } \\
\hline & $\begin{array}{c}0.24 \\
(0.83)\end{array}$ & $\begin{array}{l}1.04 \\
(3.50)^{* * *}\end{array}$ & & $\begin{array}{c}0.29 \\
(0.75)\end{array}$ & $\begin{array}{l}1.20 \\
(3.07)^{* * *}\end{array}$ & \\
\hline
\end{tabular}

Panel B: High Incremental Option Grant vs. Low incremental Option Grant

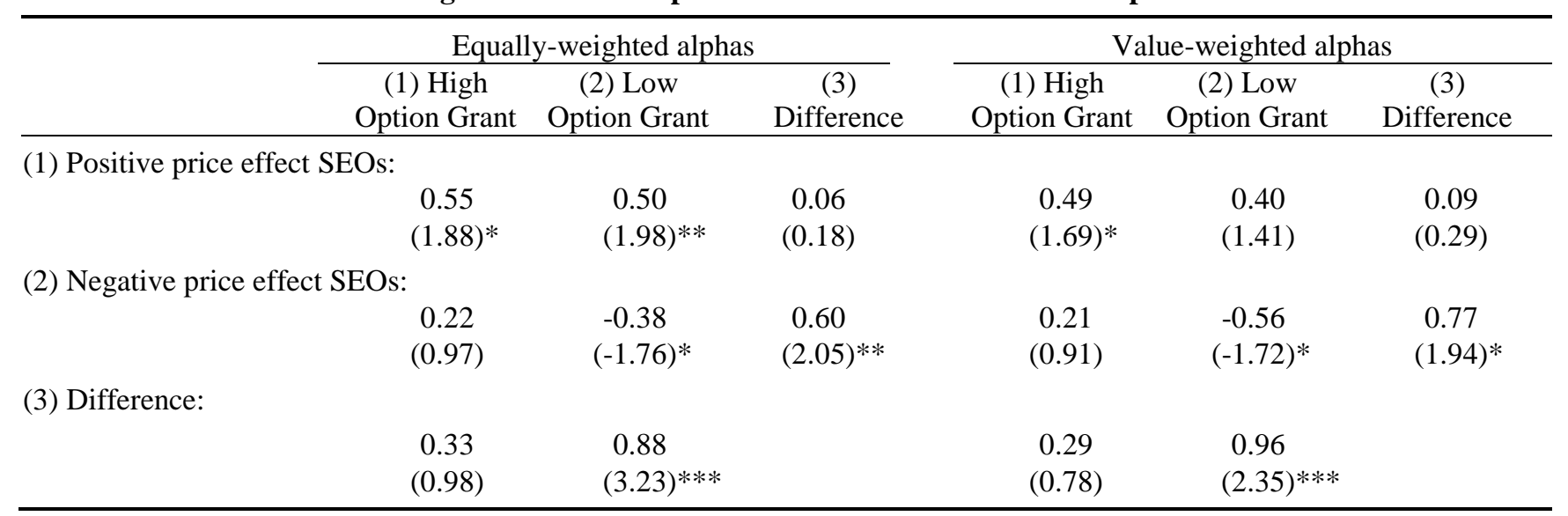

